\title{
Production Strategies for Successful Cultivation of Asian Vegetable Crops
}

K.M. Palaniswamy ${ }^{1}$ and Usha R. Palaniswamy ${ }^{2}$

Additional IndeX wORDs. tropical vegetables

SUmmary. There is an amazing variety of Asian vegetables that, even today, are largely unknown in the United States. However, as Asian populations increase in numbers and diversity, local demand has increased and opened up opportunities to identify suitable crops for successful cultivation and possible export of these vegetables back to Asian countries. Production strategies for successful cultivation of Asian vegetable crops include the identification of suitable species; access to genetic material and germplasm collections; evaluation of imported genotypes; development of technologies, skills, and resources to collect production data; monitoring of the risks from pests and diseases; identification of new pests and pest management techniques; and organization of research on postharvest handling, packaging, and transport for a wide range of products to meet the consumer demands.

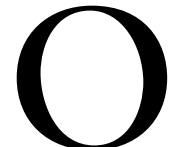

$f$ the estimated world diversity of 250,000 plant species (Takhtajan, 1969), only about 80 to 94 species are listed as food plants (Purseglove, 1968; Simmonds, 1976). Some of the forces driving the search for new crops and a variety of foods from Asian cultures include the strong associations between phytochemicals identified in a number of plant species and lower risk of chronic diseases, the vegetarian sector, flourishing health food industry, and the immigration of Asians into the United States. In our modern world of mixed cultures, it is often difficult to define which are Asian crops. A number of the Asian crops have been domesticated in North America and traditionally these have been the edible plants cultivated by Americans of Asian descent. Most Asian vegetable gardens in China, Japan, Thailand, Vietnam, and neighboring countries currently include Asian and non-Asian new world crops because of their acceptance into the daily diets. 
The number of crops that are available in grocery and ethnic food stores has increased tremendously in the past decade and include tropical vegetables such as indian eggplant and chinese eggplant (Solanum sp.), chinese cabbage (Brassica rapa var. pekinensis), chinese mustard (Brassica juncea var. rugosa), moringa leaves and pods (Moringa indica), leaf amaranth (Amaranthus sp.), bitter melon (Momordica charantia), turmeric (Curcuma longa), white radish (Raphanus sativus), and a variety of fresh beans [Fabaceae (Leguminosae)] and gourds (Cucurbita sp.).

Not all attempts to introduce new crops for production are successful. Before introducing the desired crop, research should determine if the crop can satisfactorily perform in a given climate, if it can gain acceptance by consumers, and if the new crop is economically viable. Upon identifying the plant species suitable for cultivation, it is important to gain access to genetic material, evaluate imported genotypes, and develop technologies, skills, and resources to coordinate production statistics. In addition, all pests and diseases, pest management techniques, postharvest handling, and packaging and transport methods need to be identified.

Most Asian crops commonly found in the United States are regularly cultivated crops in their countries of origin and/or use, for which local standard production methods have been developed. The best way to begin developing production strategies in the United States should be to start with the conventional production practices and where necessary make changes to suit the conditions in the United States. The purpose of this paper is to discuss the various production strategies for Asian crops with specific reference to tropical vegetable crop species.

\section{Soil requirements, irrigation, and fertilizer}

Most Asian vegetable crops can be grown in a wide range of soil types from sandy soils to heavy textured clay loams, but well-drained soils high in organic matter are preferred (Tindall, 1983). In Asia, where these crops are regularly cultivated, the ground is normally prepared with large quantities of organic matter like compost and manure that provide nutrients needed by the crops. Often the crops will be grown without additional fertilizer application during the growing season. However, if the soil is a sandy loam that is low in organic matter, additional fertilizers are added. The ideal $\mathrm{pH}$ range is $\mathbf{5 . 5}$ to 7.0 . Lime can be applied if the $\mathrm{pH}$ is below 5.5. A higher $\mathrm{pH}$ of 7.6 is desirable for Brassica sp. that are affected by club root (Plasmodiophora brassicae).

The amount of fertilizer depends on the soil type, crop rotation, and previous fertilizer history. Have the soil analyzed to develop an accurate fertility program before soil preparation. Consider each of these variables while deciding the dosage, frequency, and method of application. Avoid applying fresh manure because it may have a high level of nitrogen and burn the plants. Additionally, the U.S. recommendations are not to apply fresh manure within $120 \mathrm{~d}$ of harvest. Since many of the Asian vegetables and herbs are harvested in less than $120 \mathrm{~d}$, it is better to incorporate organic farmyard manure before planting.

When planning irrigation methods and frequency, consider the root systems of the plant species, the prevailing temperature, and other climatic conditions. Proper irrigation will increase yields and help prevent nutritional and physiological disorders. Too much watering can cause root death resulting in poor quality produce. In areas where frost is a problem, commercial growers may need to use greenhouses, high tunnels, or other protective covering to extend the growing season and to grow more of the tropical Asian vegetables that normally require higher temperatures.

\section{Weed control}

If crops are to be directly seeded, a weed-free seedbed is essential for crop establishment and growth. Weed control is also important in the field to allow transplanted crops to become established and also for pest and disease control. To begin with, application of U.S. registered broad-range herbicides (e.g., paraquat, glyphosate) may be effectively used to control weeds. Later, based on the effectiveness of these herbicides, one can develop a more specific weed control schedule for individual crops. Hand cultivation and other weedcontrol methods such as mulching can be used.

\section{Diseases}

Downy miLDew. Downy mildew is more prevalent when the weather con- ditions are cool and wet. The disease is caused by the fungus Peronospora parasitica and is a common disease of cruciferous crops. Symptoms of downy mildew include yellow to brown spots on the top surface of leaves that correspond to a white fungal growth on the underside. Chinese broccoli (Brassica oleracea var. alboglabra) appears to be more susceptible than most other Asian cruciferous vegetables. The disease is most serious in seedlings, and infected young plants can die.

Bacterial SOFt ROt. Bacterial soft rot caused by Erwinia carotova is common to all vegetables and can cause significant crop loss. Soft mushy areas develop on old leaf bases near the ground and move into the head, which can disintegrate into a brown slime. Chinese cabbage is particularly susceptible.

Club root. Club root is one of the major diseases of cruciferous crops and is caused by the soilborne fungus Plasmodiophora brassicae. The roots of infected plants swell and become distorted and the first symptoms are stunting and or wilting during the day. Plants wilt and collapse as the disease advances. Acid soils are more conducive to club root development and liming to raise the soil $\mathrm{pH}$ may help. Many varieties of chinese cabbage are very susceptible to club root, but there are also resistant varieties that can be grown.

White Leaf SPOT. This disease is caused by the fungus Pseudocercosporella capsellae and is first observed on older leaves. Light brown to white spots about $10 \mathrm{~mm}$ (0.4 inches) in diameter develop on leaves when infected. The disease is most common in wet autumn and early winter conditions. The fungus survives on seed and plant debris of cruciferous plants. Effective control methods include the removal of cruciferous weeds near crops, plowing of crop residue back into the soil, and hot water treatment of seeds before planting.

It is unlikely that there will be fungicides registered for the control of specific diseases of Asian vegetables in the United States, but the same general fungicides (e.g., malathion, dithion) used on other species may be useful in controlling fungal diseases.

\section{Insect pests}

Good farm hygiene is important in effective pest control. Old crop residues need to be removed immediately for pest control as otherwise these will act as a reservoir for pests and allow 
pest populations to build up making control more difficult. The use of tolerant cultivars and good crop hygiene will help reduce disease outbreaks in the fields. Some of the major pests harming the Asian vegetable crops are as follows.

Diamondback moth. Cabbage moth or diamondback moth (Plutella xylostella) can be a potential major problem because it appears to have developed resistance to a number of major pesticide groups. It can be controlled by developing a strategy based on alternating chemical groups.

Aphids. Aphids are small insects found on the underside of leaves or concentrated around the growing point. They have gray or green globular bodies and spindly legs and may be winged or wingless. They suck the plant sap, eventually killing the plant, and can also transmit virus. Commonly found aphids include brassica aphids (Brevicoryne brassicae), soybean aphid (Aphis glycines), and melon aphid (Aphis gossypii). Some virus diseases transmitted in Asian vegetables include turnip mosaic virus (TMV) and cauliflower mosaic virus (CMV). Aphids that are most active in autumn transmit both viruses. Aphids can be controlled by using sticky traps, spraying with insecticidal soap water, or by biological control using predators such as the lady beetle (Coccinella septempunctata).
IMPROVED CABBAGEWORM. The caterpillars of the cabbageworm (Pieris rapae) are larger than those of cabbage moth and are dull green in color. They feed on the leaves of the cabbage. The adults are white with black markings and are very common around crucifer crops.

WeEvils. Vegetable weevil (Listroderes sp., Leptinotarsa decemlineata) can attack a wide range of vegetables. The larvae are pale yellow or cream colored, thick set, curved, and become greenish yellow or green when fully mature. They feed at night, causing significant damage by burrowing. During the day they may shelter in the soil or the growing point of the plant.

Leaf miner (Liriomyza brassicae) and budwoffils (Diaphania sp.) are also known to damage chinese broccoli, chinese chard (Brassica rapa var. chinensis), and chinese flowering cabbage (Brassica rapavar. parachinensis).

\section{Literature cited}

Purseglove, J.H. 1968. Tropical crops: Dicotyledons. Wiley, New York.

Simmonds, N.W. 1976. Evolution of crop plants. Longman, London.

Takhtajan, A. 1969. Flowering plants: Origin and dispersal. Oliver and Boyd, Edinburgh.

Tindall, H.D. 1983. Vegetables in the tropics. AVI Publ. Co., Inc. Westport, Ct. 